\title{
Friedrich Ratzel, Lebensraum and the death motif
}

This intervention explores 'death' as an interpretive key both to Friedrich Ratzel's Lebensraum essay and his oeuvre more generally. Ratzel, I argue, was preoccupied with death in a number of ways, including a biogeographical concern with extinction, an ethnological interest in cannibalism and a fascination with the ruins of exterminated civilisations. Indeed, Ratzel grappled with the aesthetics of death itself in the later stages of his life. An appreciation of Ratzel as a thanatological thinker, I argue, opens the door to a recognition of his place not just at the inception of modern geopolitics but as an early thinker of biopolitics too.

Whether it is in examinations of global biosecurity, the global war on terror or of more-thanhuman connectivities, the politics of life and earth continues to preoccupy early twenty-firstcentury geographers. Whereas geo- and biopolitics are frequently said to be intimately intertwined forms of power, they are in fact often approached as analytically dissimilar phenomena. ${ }^{1}$ Whilst geopolitics is predominantly understood as a discourse on international statecraft, biopolitics is read as a governmental practice of domestic politics. And yet, there are perhaps few places in which the entanglement of geo- and biopolitics is as unambiguous as in Friedrich Ratzel's 1901 Lebensraum essay. Indeed, even the most cursory reader of his essay will note the degree to which biology, geology and politics are inextricably interlinked. It is thus perhaps no surprise that both terms - geopolitics and biopolitics - were popularised by one of Ratzel's keenest followers, the Swede Rudolf Kjellén. ${ }^{2}$

This commentary on the Lebensraum essay offers an examination of Ratzel not as a geopolitical thinker - this, after all, is a well-trodden path - but as a political theorist of life and death. I want to foreground in particular the question of death, which has of course played a crucial role within the most popular conceptual articulations of biopolitics. As social theorists like Giorgio Agamben and Michel Foucault have argued, we can find within the seemingly protective practice of biopolitics, the concern for the health and growth of populations, a much less benign policy of excluding forms of life that are deemed dangerous and unworthy. ${ }^{3}$ If we want to explore Ratzel and his Lebensraum concept as crucial to the history of modern biopolitics we have to address the question as to whether we can find in Ratzel the seeds of thanatopolitics.

As I will show in what follows, this question must be answered in the affirmative. Indeed, the dead frequently perform crucial roles in Ratzel's writing, ranging from the obvious ways in which fossils and skeletons are invoked as archaeological evidence to his more obscure speculations about 'bloated animal corpses'4 that he believed inspired humans to build inflatable boats. ${ }^{5}$ Indeed, Ratzel's social Darwinian preoccupation with the logic of survival necessarily means that he is always also writing about survival's opposites disappearance and extinction. Whereas much of Ratzel's writing examines extinction in the animal and plant world, he was also mesmerised by the ruins of fallen civilisations. Indeed, in the final stages of his own life he became interested in the aesthetics of death itself. The death motif has crucial implications for the history of biopolitics, in which Ratzel, or so I argue, needs to be placed in a more prominent position. Given the notable absence of biological racism from his work, ${ }^{6}$ his political geography has long been seen as being at odds with Nazi biopolitics. And yet, Ratzel's preoccupation with extinction and his later aestheticisation of 
death (thanatophilia) in many ways prefigured the twentieth century's most thanatopolitical regimes.

\section{Extinction and extermination}

Perhaps the most crucial way in which Ratzel's concern with the finitude of life appeared in his academic work is in the concept of extinction, which he developed both in his biogeography and his human geography. As with many of his other concepts, Ratzel was keen to disassociate these ideas from other evolutionary theorists (including Darwin himself) by giving them a fundamentally spatial twist. Ratzel's spatial logic of extinction crystallised perhaps most unambiguously in his Lebensraum essay, where he argued that '[c]learly, the limitation of living space on earth demands that an old species vacate the space that a new one needs to develop'. 'In this sense', he continued, 'new creation and progress presuppose retreat and demise. It is the same as with the death and birth of individuals'. ${ }^{7}$ Thus, the very idea of survival, so crucial to Darwin's followers, always already assumed the possibility of not surviving. Nations, much like species of primroses or caterpillars, were bound to disappear if they failed to assimilate to their environment.

Ratzel thus distinguished conceptually between flexible and inflexible organisms but not between the extinction of humans and non-humans. We get a sense of this when Ratzel discussed another of his key concerns, the relations between the earth and the spatial boundary:

In all realms of life, life's grip on the soil becomes weaker in the border regions. Speedy reduction and early extinction are the fate of plants, animals and peoples that live near the borders of the oecumene. ... The invasion of the French in Canada and Nova Scotia, and the English in Virginia, initiated the retreat of the North-American Indians at the easternmost edge of their area of distribution, progressing slowly across the entire continent, like an organ or carrier of all influences that were ruinous to that little people (Völkchen). The retreat of the bison, the elk, the Canadian moose and other animals happened in a similar manner. ${ }^{8}$

There is an interesting slippage in Ratzel's essay between the logic of extinction and that of extermination. At one point he speaks of the 'dying out or extermination of large animals on islands'.9 Unlike the term Aussterben (extinction), Vernichtung (extermination, annihilation or total destruction) crucially assumes agency. Whereas extinction takes a passive construction, extermination is an active process. Ratzel described the colonisation of the Americas by European settlers as a 'struggle for extermination' (Vernichtungskampf). 'The losers', he held, were the indigenous Americans 'who had but a weak grip on the soil'. ${ }^{\text {o }}$ There is little room in Ratzel's intellectual universe for pity for those who become extinct, for as one species or tribe disappears, its soil is 'immediately occupied by another, as if that other had already been waiting for an expansion of its living space'. ${ }^{11}$ He thus assumed time (both geological and historical) to operate as a cycle, rather than as progress or decline.

Whilst Ratzel was willing to accept that agriculture, forestry and hunting had led to the extinction of certain animal species and individual human races, he did not contemplate the extinction of humanity. Ratzel, after all, argued in the Lebensraum essay that the living spaces of the dinosaurs were simply shrunk by more adaptable mammal species. ${ }^{12}$ Extinction and extermination, for him, were not so much an end product as a new beginning:

A complete extermination of all life across a wide area cannot, however, be accepted even in the case of the Ice Age. While no more than a few decades ago no 
one doubted that fire, water or ice had intermittently destroyed all life across vast regions, after which new life emerged out of the dead soil, today we reject this catastrophe even in the one case where something like this might seem possible. ${ }^{3}$

It is in his 1885 three-volume Völkerkunde (translated into English in 1896 as History of Mankind) that we get a clear sense of Ratzel's understanding of time, which underlies his concepts of extinction and extermination. ${ }^{14}$ Here he argued that 'all that we call progress of civilisation, may better be compared with the upward shoot of a plant than with the unconfined flight of a bird; we remain ever bound to the earth and the twig can only grow on the stem'. 'Human nature', Ratzel continued, can 'raise its head aloft in pure ether, but its feet must ever rest on the ground, and the dust must return to the dust'. ${ }^{15}$ It is in this work that the dead take centre stage, as Ratzel wrote at great length about burial rituals amongst what he referred to as 'natural' or 'uncivilised races'. Ratzel was obsessed by sinister themes such as human sacrifice, head-hunting, infanticide and cannibalism, and described these gruesome practices - for many of which the empirical evidence is sparse - with the thoroughness of a pathologist conducting an autopsy. The following describes death rites in Fiji and New Guinea:

Burial within the hut is customary in Fiji. Amongst the Motus of Port Moresby the only sign of mourning is the incessant beating of drums for three days. When this is over, the grave is dug in front of the house, the dead body laid in a mat, and a little hut is built over the grave. After some time, the grave is opened, the corpse taken out and smeared on the elbows and knees with red ochre, while the widow smears herself with the decaying flesh. Then the dead man is put by again, and the little sepulchral house is gradually pulled to pieces, so that no trace of the grave is left. ${ }^{16}$

Ratzel explains similar rituals on the Gilbert Islands, where the widow slept under the same mat with the corpse of her husband 'until the head falls off the body', after which the skull was cleansed and the widow carried it with her for the rest of her life. ${ }^{17}$ Yet a few pages later he casually discusses the way in which infanticide in Australia was committed by 'thrusting a stick through the ears and into the skull' of the infant. ${ }^{18}$

Ratzel's observations of these grisly scenes are continuously presented in a puzzlingly descriptive manner, often without drawing any wider conclusions. And yet, the endless visual depiction of burial sites, coffins, human skulls and mummies in his book gives his readers the subliminal message that there hangs over these non-Western peoples the shadow of death. In this Ratzel is very close to other Darwinian thinkers of his time who also saw so-called 'primitive peoples' as bound for self-extinction. ${ }^{19}$ Ratzel implied that these extinctions would eventually make way for an expansion of other races, chiefly of course the white race. Interestingly, when discussing 'the Europeans' on the final pages of his third and last volume, he did not focus on burial rituals. ${ }^{20}$ In contrast, he repeatedly spoke of the shrinkage and retrogression of 'primitive races'. He suggested that cannibalism and human sacrifice, both of which he deemed to be widespread amongst non-Western societies, were in fact symptoms of decay. He saw these societies as fragile due to their narrow economic base and the thinly spread nature of their population. In this way, he used 'the last Tasmanians' as an example of a recent extinction. Ratzel's discussion is brief here but there are harrowing images of the last Tasmanian man and woman - William Laney and Truganina - accompanying his text. And although Ratzel applauded the Tasmanians' cheerful and good humoured nature, he also described them as particularly low in culture and development, thus implying an inevitability to their decline. 
Ratzel stated in the Lebensraum essay that the jury was still out as to the reasons why 'primitives' became extinct. ${ }^{21}$ In his 1891 Anthropogeographie, however, he tried to think through the question of national demise and extinction in a more systematic way. Here, Ratzel proposed the idea of a 'pathology of world history'. For just as it was essential to think in terms of stronger and weaker races, the former pharmacist suggested, it was also important to assess a race's 'Hippocratic characteristics'. ${ }^{22}$ Although the book initially seems to approach the question of ethnic extinction in a more nuanced and emotional way - he noted that the extinction of indigenous populations saddened him on a number of occasions - his overarching aim remained one of understanding scientifically the underlying reasons for these extinctions. After describing in detail the detrimental impact of the 'superior' white settlers on the indigenous populations, he argued, this time explicitly, that the contact with these settlers had only increased a process already under way before their arrival. Ratzel thus portrayed this as a self-extermination, an 'inner process of decomposition' which he saw as provoked by external intrusion. In the course of this process, destruction and renewal combined 'but in the way that at first the former becomes operative, after which the latter tills the field upon the soil, which is [still] strewn with ruins'.23

Ratzel saw this process of self-extermination as rooted in a myriad of interlinking causes, including unhealthy lifestyles, low sexual morals, and the aforementioned infanticide, human sacrifice, head-hunting and cannibalism, all of which marked these societies out as 'primitive'. He was keen to emphasise the connection between these deadly practices, arguing, for instance, that where one found head-hunting and human sacrifice one also found cannibalism. 'Whether it is the devouring of a still twitching heart or the slurping of fresh brain', he suggested, there always existed an intimate connection between the quest for enemy scalps and 'the desire to eat their owners'. ${ }^{24}$ Even where white settlers had brought 'the torch of civilisation', and cannibalistic practices had disappeared on the social surface, the natives could still be seen to drink from human skulls if left unsupervised by the colonisers.

\section{The aesthetics of death}

Ratzel operationalised the death motif in what is perhaps his best-known work, the 1897 Politische Geographie. ${ }^{25}$ Concerned less with nations and races than with territorial states, he argued, that ' $[t]$ he fragments of a decaying state live on and form new states'. The death of states was thus not to be understood as a 'downfall' but rather as a 'reshaping'. 'A bigger state dies, smaller ones emerge in its place', he continued, which made it 'mistaken to assume that the growth of states will have reached the end once one state has come to encompass the entire globe'. ${ }^{26}$ He argued that Germany had grown naturally out of the moribund mosaic that the Holy Roman empire had left behind. Thus Ratzel revealed again his cyclical understanding of history, in which the struggle over space could only produce instable balances of power and temporary territorial configurations, before the latter would themselves collapse and give way to new patterns. While he reinforced his earlier conclusion that decay set in more quickly at lower stages of state development, he also used the example of Austria-Hungary and a number of other European cases to show how these processes could occur even amongst the great powers of the Old World.

Ratzel returned to the question of decay in his 1898 popular science book Deutschland: eine Einführung in die Heimatkunde (Germany: An Introduction to Local History and Geography). ${ }^{27}$ It was here that he depicted in great detail the geomorphology of German lands, along with their animal, plant and human life. But whilst he was primarily preoccupied with the spatial dynamics of life and its relationship to the earth, his narrative also had a strikingly morbid undertone. Ratzel was struck by the coastal erosion along the clayey coasts of Farther Pomerania' on the German Baltic and vividly described the case of a graveyard that had been eroded by the sea so that 'coffin planks and bones' were sticking out of the ground..$^{28}$ This 
observation should perhaps be read as more than a side note, for Ratzel thought of the burial of the dead as a reproductive purpose that connected the nation to the soil on which it grew. For him, in other words, the earth was not just a vital natural resource on which the state as organism would sprout. Instead, it was the very material into the folds of which the state would eventually return. The violence that affected human societies was, in other words, ontologically similar, if not exactly the same, as the geologic forces that ripped into the earth's surface.

When describing - in a more geo-poetic vein - the blackness of leaves in late autumn, Ratzel observed that although they were not quite as beautiful as the brown and yellow of previous weeks, they were beautiful in that they constituted the natural precondition for the earth's fertilisation and renewal in spring. ${ }^{29}$ In this sense, for Ratzel natural forces were always simultaneously destructive and creative. Importantly, he saw these energies at work amongst humans in much the same way. On his travels to the United States in the 1870s he observed a scene in a railroad eating house in Jesup, Georgia, where a young couple had just sat down for breakfast. Whilst Ratzel described the mother as 'a very healthy enterprising-looking woman', he observed that her husband was stricken by illness and 'corpse-like'. ${ }^{\circ}$ With considerable emotional detachment he continued:

She later brought in their lovely, cheerful baby whose joyful young life seemed to be of more concern to her than the hopelessly disintegrating one of her husband. The excusable cruelty of nature seemed to dominate their thoughts. ${ }^{31}$

The same logic can be observed in Ratzel's urban geography. On a number of occasions on this same journey he highlighted how quickly the urban fabric had recovered after fires in cities such as Boston and Chicago. Death, he observed, so effortlessly gave way to life in the New World..$^{32}$ Even when writing about matters of biogeography he urged his readers to learn from the inevitable end of organic beings, 'which return to the very dust from which they were born'.33

This cyclical understanding of time, which unites Ratzel ideologically both with political realism and with National Socialism - the idea of a thousand-year Reich rather than one that is eternal - comes to the fore in particular in the spatiotemporal figure of the ruin, which played a crucial role both in his discussion of previous high cultures ${ }^{34}$ and in his travels to the United States. It is in the latter that he became preoccupied by the ruins of the recent civil war and the dilapidated settlements left behind along the American frontier. It is his discussion of these ghost towns that allowed him to ponder that '[1]ife is indeed not stronger than death'. ${ }^{35}$ Ratzel was mesmerised by 'ruin landscapes' (Ruinenlandschaften) where 'a whole culture has been annihilated without any new life blossoming from the ruins' ${ }^{36}$ Not able to conceal his admiration for the more monumental traces of civilizational decline, he argued that a nation 'that leaves humanity with witnesses of its existence, lives on in its works'. 'All others', he explained, were 'just dead, even if an ancient inscription conveys their names to us'. ${ }^{37}$

\section{Pharmacist, warrior, scientist}

Neither Ratzel's concept of extinction, his fascination with cannibalism nor his ruin gaze may be atypical for a man of the late nineteenth century who was raised as a Lutheran in a Catholic part of Germany and who was under the influence of both Darwinism and German Romanticism. And yet, it is the particular combination of these preoccupations that points to something perhaps more extraordinary. Indeed, Ratzel's posthumously published Jugenderinnerungen (Memories of youth) reveal that he may have adopted his fascination with death at a very early stage in his life. Not only was the young Ratzel a keen collector of fossils, 
but he also kept the skull of a mouse amongst his private possessions, right next to a curl of his mother's hair. ${ }^{38}$ As a child, Ratzel had already developed an animist streak. He was convinced that even those parts of the world that were inorganic and supposedly dead were ultimately alive. ${ }^{39}$ It also emerges from his memoirs that Ratzel experienced a number of traumatic events that may have had a formative influence on him, including his unreciprocated love for Luise, a one-eyed girl (he describes his fascination with her dead eye, which seemed to cast 'its shadow over the world around her') and his being forced to leave the parental home at an early age to become a pharmacist. He also recounted an episode in his autobiography, which despite being narrated through the medium of fiction, has all the hallmarks of a suicide attempt. The story recalled his experience of experimenting with various drugs when working as a pharmacist:

\begin{abstract}
Why shouldn't I try it, to fly? Here it stands in a stone jar, that cherry laurel, a liquid whose prussic acid lends it a biting but elegant scent. I am not frightened by the skull above the archaically ornamented label 'Aqua Laurocerasi'. The hydrogen cyanide content is not too strong. Perhaps its effect will just be anaesthesia, dream and return, but perhaps it is death. What difference does it make? And here is an old glass of Bohemian crystal, the clarity of which I have long admired. How innocent that blueish venom shimmers. A long sip, a second, I can already feel my hands tremble..... ${ }^{\circ}$
\end{abstract}

It is only after days of slumber that Ratzel finally awoke, his limbs feeling broken, his head numb. Upon recovering, however, Ratzel realised the value of his life to those who were close to him and ended up feeling awfully embarrassed about the entire affair. Interestingly, he narrated the experience not merely in a language of horror and guilt but framed it through a morbid Romanticism. Death, he noted, was 'the most beautiful thing that can be thought'. ${ }^{41}$ Ratzel mastered each of these traumatic experiences, or so he came to believe, with a degree of emotional detachment that would come to guide him in his later dealings with the dead. As a soldier in the Franco-Prussian war, during which he lay for hours in the muddy soil about which he would later obsess in his writings, Ratzel was forced to come face-to-face with death again.

Ratzel had joined the war with great enthusiasm and remained tremendously positive about his military experience throughout his life, despite the horror he had to endure. As he recounted in his essays 'Images from the war with France', he had suffered a heavy head injury near Auxonne, in Burgundy, and had to endure a significant period of the war in a military hospital. He began the description of his time in the hospital by telling the story of how he awoke feverishly and freezing in the midst of a gruesome scene that reminded him more of an abattoir than a hospital..$^{42}$ Indeed, the first thing that Ratzel spotted there was a sawn off human leg, placed in a bucket. But rather than being paralysed by horror, he later claimed to have envied the person who had lost the leg for that soldier would have undoubtedly been given a warmer bed than his own.

Due to his head injury, Ratzel was forced to remain in the military hospital, where, as a trained pharmacist, he helped the nurses and doctors with some of the badly wounded patients. He recounted in particular the repeated bandaging of a fellow soldier who had a gunshot wound straight through his face, which had 'ripped out both eyes and his upper nasal bone'. ${ }^{43}$ Ratzel saw this horrific experience as an opportunity to 'practice viewing' such wounds, a skill that prompted him to muse on the 'aesthetics of ugliness' (Ästhetik des Häßlichen). ${ }^{44}$ And yet, even amongst those who were at death's door, Ratzel observed a perpetual and inextinguishable will to live - a theme that would come to haunt his academic writing for decades to come. 
Ratzel's memories of this time, from encounters with French civilians to the description of near-death experiences amongst his fellow soldiers, reveal him as an often strangely unemotional observer. His biographer Günther Buttmann ${ }^{45}$ sees in Ratzel's account of the war 'the shock at the suffering and dying on the battlefield'. And yet, the latter is not always explicit in Ratzel's account. Towards the end of his life he noted in passing that his experience of the military had enriched him, and suggested that his fallen comrades had lived on in him.

Ratzel's preoccupation with death - and his noticeably detached way of approaching it - followed him throughout his career. During his travels to the United States in the 1870s, for instance, he frequently visited church yards and cemeteries, and by the end of his academic career he had written a staggering two hundred obituaries. ${ }^{46}$ Indeed, Ratzel deemed the practice of writing obituaries so important that in 1894 he found himself forced to write an angry article to complain that his contemporaries were no longer taking the practice of necrology seriously enough. ${ }^{47}$

In his memoirs of the Franco-Prussian war he depicted the way in which army doctors abandoned cases which they considered too difficult to treat by hanging a sign around the neck of these soldiers that read 'moribund'. Interestingly, Ratzel described a scene in which a soldier himself asked to be classified in this way and thanked the doctors for doing so. By concluding that this man had 'gladly' consigned himself to death, ${ }^{48}$ Ratzel unknowingly put his finger on the central dynamic of Foucaultian biopolitics: the simultaneous fostering and abandoning of life and the state's medicalizing grasp at the physical bodies of its population.

It was also Ratzel's time in the military hospital that prompted him to muse on the ontological 'easiness' of death and the inability of separating it clearly from life. ${ }^{49}$ There is 'no mountain range or wall' between life and death, he wrote. Indeed, 'the way into the great and dark gateway' was in fact really 'rather flat'. Ratzel, who in later life returned to his Christian faith, described the experience of watching another human die as a 'sanctification'..$^{50}$ Like Foucault, ${ }^{51}$ Ratzel lamented that death had become a taboo. Instead, Ratzel felt, humans should embrace death if they wanted to find eternity. He concluded that the more life is prepared for death, the more beautiful it becomes'. ${ }^{2}$ Rather than approaching survival and extinction through the lens of scientific detachment, Ratzel came to deal with death as an aesthetic category in ways that clearly chime with the death cult introduced and institutionalised by National Socialism three decades later.

\section{Conclusion}

Ratzel's morbid preoccupation with the disappearance of nations and states did not die with him in 1904. Rudolf Kjellén, a keen Ratzelian, picked up the death motif during World War I when he compared territorial partitions in European history to 'executions'. Kjellén imagined his own nation, Sweden, in the graveyard of history. ${ }^{53}$ Another follower, Karl Haushofer, argued in the 1930 s that the many maps he used in his writing were in fact $\mathrm{x}$-rays, which were meant to discern where a state was so old that its skeleton was already shining through its skin. ${ }^{54}$ Ratzel's writing on death and ruins must have left an impression on Haushofer because he chose to include these passages in his 1941 edition of Ratzel's most notable work, Erdenmacht und Völkerschicksal (The Power of the Earth and the Destiny of Nations).55 Similarly, Richard Henning, a contemporary of Haushofer's, explained in his 1935 Einführung in die Geopolitik (Introduction to Geopolitics) that whilst young states tended to have a strong impulse to grow in space, more mature states typically started to stagnate or founded colonies. 'Old states', he claimed, 'shrink in much the same way as elderly humans do'. And yet, as Henning put it, 'very old states sometimes have to be incapacitated' if they have become 'unfit for life'. ${ }^{56}$

To conclude, it is thus necessary to explore not just the geopolitical (earthly) and biopolitical (lively) implications of Ratzel's Lebensraum essay, but the death motif that drives 
- and survives - his writing. His conception of the state as an organism and his insistence that political geographers had to be pathologists are both clearly products of his background as a zoologist and pharmacist. And yet, they also express the profoundly biopolitical space of the military hospital, which seems to have been so formative for the young Ratzel. By coating his discussion of life and death in the scientific language of his day, Ratzel naturalised not just extinction but extermination too. Thereby, his political geography ultimately laid the intellectual and scientific foundations for a twentieth-century approach to politics that saw extermination as a legitimate strategy to ensure a nation's survival. It is also no surprise that Ratzel's ruin aesthetic is congruent with the theory of ruin value propagated by Hitler's architect Albert Speer. ${ }^{57}$

In this light, it is perhaps somewhat puzzling to see that some observers have spotted an 'ecological note' in Ratzel's work,$^{58}$ allowing for an interpretation of him as an early thinker of the Anthropocene. Although Ratzel does muse in Anthropogeographie and elsewhere about the power of nature to reclaim abandoned human settlements, ${ }^{59}$ it is important not to be deceived. When Ratzel speaks of the human effects on the environment, such as the annihilation of the forests, the drying up of swamps, artificial irrigation, the disappearance of deadly animals', ${ }^{60}$ then he does so not as an environmentalist of a contemporary ilk but rather as someone who is simply trying to assess whether the human species has had more of an impact on the environment than other living beings. Ultimately, nature - with its destructive and creative forces - always wins.

\footnotetext{
${ }_{1}$ M. Dillon and L.E. Lobo-Guerrero, Biopolitics of security in the 21st century: an introduction, Review of International Studies 34 (2008) 265-292; S. Elden, Secure the volume: vertical geopolitics and the depth of power, Political Geography 34 (2013) 35-51; P. Giaccaria and C. Minca, Life in space, space in life: Nazi topographies, geographical imaginations, and Lebensraum, Holocaust Studies: A Journal of Culture and History 22 (2016) 151-171.

${ }^{2}$ R. Kjellén, Grundriss zum einem System der Politik, Leipzig, 1920, 94.

3 G. Agamben, Homo Sacer: Sovereign Power and Bare Life, Stanford, 1998; M. Foucault, 'Society Must Be Defended': Lectures at the College de France, 1975-1976, New York, 2003. See also the further elaboration of these ideas in R. Esposito, Bios: Biopolitics and Philosophy, Minneapolis, 2008.

4 F. Ratzel, Die Erde in vierundzwanzig gemeinverständlichen Vorträgen über Allgemeine Erdkunde, Stuttgart, 1881, 383.

5 All translations are the author's.

${ }^{6}$ M. Bassin, Race contra space: the conflict between German geopolitik and National Socialism, Political Geography 6 (1987) 115-134; D.T. Murphy, Heroic Earth: Geopolitical Thought in Weimar Germany, 1918-1933, London, 1997, 8.

7 F. Ratzel (1901) Lebensraum: A biogeographical study, XXX.

8 Ratzel, Lebensraum, XXX.

9 Ratzel, Lebensraum, XXX.

${ }^{10}$ Ratzel, Lebensraum, XXX.

${ }^{11}$ Ratzel, Lebensraum, XXX.

${ }^{12}$ Ratzel, Lebensraum, XXX.

13 Ratzel, Lebensraum, XXX.

${ }^{14}$ F. Ratzel, The History of Mankind, Volume I, London, 1896 (original 1885),.

15 Ratzel, The History of Mankind, Volume I, 3.

${ }^{16}$ Ratzel, The History of Mankind, Volume I, 328.

${ }^{17}$ Ratzel, The History of Mankind, Volume I, 329.

${ }_{18}$ Ratzel, The History of Mankind, Volume I, 365.

19 P. Brantlinger, Dark Vanishings: Discourse on the Extinction of Primitive Races, 1800-1930, Ithaca, 2003.

${ }^{20}$ F. Ratzel, The History of Mankind, Volume III, London, 1898 (original 1888), 731.

${ }^{21}$ Ratzel, Lebensraum, XXX.46?XXXX.

${ }^{22}$ F. Ratzel, Anthropogeographie Zweiter Teil: Die geographische Verbreitung des Menschen, Stuttgart, 1912 (original 1891), 236.

23 Ratzel, Anthropogeographie Zweiter Teil, 227.
} 
24 Ratzel, Anthropogeographie Zweiter Teil, 254.

25 F. Ratzel, Politische Geographie, München und Leipzig, 1923 (original 1897).

${ }^{26}$ Ratzel, Politische Geographie, 145.

${ }^{27}$ F. Ratzel, Deutschland: Eine Einführung in die Heimatkunde, Berlin, 1911 (original 1898).

${ }^{28}$ Ratzel, Deutschland, 158.

29 F. Ratzel, Über Naturschilderung, München und Berlin, 1923 (original 1904), 206.

$3^{\circ}$ F. Ratzel, Sketches of Urban and Cultural Life in North America, New Brunswick and London, 1988 (original 1876), 182.

${ }^{31}$ Ratzel, Sketches of Urban and Cultural Life in North America, 182.

${ }^{32}$ Ratzel, Sketches of Urban and Cultural Life in North America, 87.

33 Ratzel, Die Erde, 326.

34 Ratzel, The History of Mankind, Volume III, 16o; see also F. Ratzel, The territorial growth of states, in: J. Agnew, D. Livingstone and A. Rogers (Eds), Human Geography: An Essential Anthology, Oxford, 2005, 527. This essay was originally published in 1896.

35 Ratzel, Sketches of Urban and Cultural Life in North America, 295.

${ }^{36}$ Ratzel, Anthropogeographie Zweiter Teil, 335.

37 Ratzel, Anthropogeographie Zweiter Teil, 332.

$3^{8}$ F. Ratzel, Jugenderinnerungen, Munich, 1966 (original 1905), 28.

39 Ratzel, Jugenderinnerungen, 23.

$4^{\circ}$ Ratzel, Jugenderinnerungen, 74.

${ }^{41}$ Ratzel, Jugenderinnerungen, 74.

${ }^{42}$ F. Ratzel, Glücksinseln und Träume: Gesammelte Aufsätze aus dem Grenzboten, Leipzig, 1905, 192.

43 Ratzel, Glücksinseln und Träume, 196.

44 Ratzel, Glücksinseln und Träume, 197.

45 G. Buttmann, Friedrich Ratzel: Leben und Werk eines deutschen Geographen, Stuttgart, 1977, 35.

${ }^{46}$ Interestingly, Ratzel preferred the term Nekrolog (necrology) to the perhaps more common, though euphemistic, word Nachruf, which literally translates as 'after-cry' in English.

47 F. Ratzel, Kleinere Schriften von Friedrich Ratzel, herausgegeben von Hans Helmolt, 2. Band, Munich, 1906, XXIII; see also H. Wanklyn, Friedrich Ratzel: A Biographical Memoir and Bibliography, Cambridge, 1961, 55.

$4^{8}$ Ratzel, Glücksinseln und Träume, 201.

49 Ratzel, Glücksinseln und Träume, 200.

50 Ratzel, Glücksinseln und Träume, 230.

${ }^{51}$ Foucault, 'Society Must Be Defended', 247.

${ }^{2}$ Ratzel, Glücksinseln und Träume, 201.

53 R. Kjellén, Der Staat als Lebensform, Leipzig, 1917, 204, 215

54 K. Haushofer, Weltpolitik von heute, Berlin, 1934.

55 F. Ratzel, Erdenmacht und Völkerschicksal, herausgegeben und eingeleitet von Generalmajor a. D. Prof. Dr. Karl Haushofer, Stuttgart, 1941

${ }^{56}$ R. Henning, Einführung in die Geopolitik, Leipzig and Berlin, 1935, 90.

57 A. Speer, Inside the Third Reich, London, 1970, 97.

${ }^{8}$ S. Stehlin, Introduction, in: Ratzel, Sketches of Urban and Cultural Life in North America, xxvi.

59 Ratzel, Anthropogeographie Zweiter Teil, 340.

6o Ratzel, Die Erde, 429. 